\title{
Philosophical and Logical Ideas of Representatives of Kyiv-Mohyla and Moscow Slavic-Greek-Latin Academies at the Turn of the 17 th -18 th Centuries
}

\author{
Vitaly Ivlev \\ Moscow State Technical University named after N.E. Bauman \\ Financial University under the Government of the Russian Federation \\ Moscow, Russia \\ E-mail: vitalijivlev@yandex.ru
}

\author{
Vladimir Inozemtsev \\ Moscow State Technical University named after N.E. \\ Bauman \\ Financial University under the Government of the Russian \\ Federation \\ Moscow, Russia \\ E-mail: inozem_63@mail.ru
}

\author{
Mikhail Oseledchik \\ Department of Philosophy and Social Sciences \\ High School of Printing and Media Industry \\ Moscow Polytechnic University \\ Moscow, Russia \\ E-mail: balu13@yandex.ru
}

\begin{abstract}
This article considers the philosophical and logical constructions of representatives of the "Russian scholasticism"- teachers of Orthodox spiritual educational institutions: Kyiv - Mohyla and Moscow Slavic - Greek - Latin academies. The paper studies the development of the domestic logical tradition in the context of the formation of Russian philosophy in the second half of the 17th - early 18th centuries. The philosophical and logical ideas of representatives of the "Russian scholasticism" are studied on the example of the works of such thinkers as Innokenty Giesel, Stefan Yavorsky and Theophanes Prokopovich. As the most prominent representatives of the philosophy and logic of the Moscow Slavic-Greek-Latin Academy, the creators of this academy consider the Likud brothers. The philosophical and logical ideas of the representatives of "Russian scholasticism" are explored in the general context of the development of world philosophy from antiquity to the New Age.
\end{abstract}

Keywords-philosophy; logic; Russian scholasticism; Kiev Mohyla Academy; Moscow Slavic - Greek - Latin Academy

\section{INTRODUCTION}

Recently there has been a steady scientific interest in religious and philosophical problems in the framework of the study of Russian philosophical consciousness, which allows not only to ascertain some intellectual achievements along this path, but also to identify existing gaps. One of such gaps is the study of the formation of the philosophical and logical tradition in Russia in the 17th - early 18th centuries in Kyiv Mohyla and Moscow Slavic - Greek - Latin academies. The authors of this article have previously attempted to fill this lacuna [1] [2]. It should be noted that in this period, philosophy and logic become a powerful tool for the emergence of a unique type of rationality - the rationality of the European model for the New Age era, but in a special Russian way.

\section{PHILOSOPHICAL IDEAS OF THE REPRESENTATIVES OF THE KYIV-MOHYLA ACADEMY IN THE SECOND HALF OF THE XVII - EARLY XVIII CENTURIES}

Let us begin our acquaintance with the philosophical ideas of the representatives of the Kyiv - Mohyla Academy of this time period from consideration of the ideas of such a prominent representative of it as Innokenty Giesel. $\mathrm{He}$ is known as the author of the extensive philosophical course "The Work on the Whole Philosophy", which he read in the walls of the Kiev Academy in 1645 - 1647. This course influenced the academic tradition of the late 17th - early 18 th centuries. There are also such philosophical works by Giesel as "Philosophical axioms" and "World and God to man".

Actual philosophical views of Giesel can be interpreted as almost a classic example of "slavia scholasticism". Nature Giesel defined "as quidditas and the essence of each thing", and "quidditas" is "the very being (entitas) of a thing" [3]. Following Duns Scott, Giesel distinguishes three states in nature, namely, a state of indifference, or nature itself (nature here is indifferent to its accidental predicates), the second is the state of nature relative to existence (the state of individuality), and the third is the state of nature in the abstraction of the mind, where nature regains its ideal unity. Knowing the general nature, the human mind understands the laws, according to which the transition from the first (potentially common) to the second state of nature takes 
place. This transition is carried out by means of special, immanent forms of nature, which, in the interpretation of Giesel, resemble the elementary categories of formal logic. These are the logical operations of the mind, which, abstracting from matter becomes capable of perceiving pure entities. Giesel, tries in every possible way to bring the common to matter closer, without permitting their mixing, in which the synthesis of Neo-Platonism with peripatetic's finds its expression. Characteristic in this respect is his maxim: "The necessary precondition for existence is individuality" [4].

Other features of Giese's philosophy include the desire to explain the natural processes and phenomena that comes from them, although the above synthesis of Neo-Platonism with peripatetic's also makes itself felt here. God, according to the teachings of Giesel, dwells everywhere, being involved in every entity, and thus pantheistical in touch with the material world. Giesel, himself, however, held creationist positions, the deviations from which are explained by the complexity of the philosophical synthesis he undertook.

The second major representative of the Kyiv - Mohyla Academy and the South - Russian scholarship is Stefan Yavorsky. The philosophical course read by S. Yavorsky in the Kyiv - Mohyla Academy in 1693 - 1694 has a rather long name, characteristic of the Baroque style: "Philosophical competition opened in the arena of the Orthodox Kiev Mohyla Gymnasium by Russian athletes for the glory of the one who, being a traveler free from sin and the only begotten son of his father, entered the path of multiplying the glory of his most beloved mother, who passed quickly through the Judaic hills". The name of the course itself indicates its polemical nature. The word "agonium", as noted by I. Zakhara, in this context means not only competition, competition, dispute, but also an uncompromising struggle [5]. Therefore, throughout the course of the course, he argues with scholastic scholars, ideologues of the Catholic counterreformation, the philosophical basis of which was a modified, adapted to new historical conditions, Thomism, although outwardly the "Philosophical competition ..." looks the same as the philosophical courses taught in Catholic schools in Poland and Lithuania. The polemics with the followers of the philosophical teachings of Thomas Aquinas S. Yavorsky does with the same scholasticism, and this manifests itself when the professor, using scholastic logic, refutes Catholic dogmas not recognized by the Orthodox Church.

Most sections of the course the professor begins with the expression "with the help of God, under the guidance of Aristotle". At the same time, Yavorsky's aristotelianism differs significantly from the Aristotelianism of the followers of Aquinas. Aristotle did not interest S. Yavorsky as an authority by means of which philosophy can be placed at the service of theology, but as a logician and naturalist. Philosophy and theology for S. Yavorsky are two different sciences that have different subjects of study, and in the development of philosophical problems, logic and common sense are more important than the assertion of any authority [6].
Another notable representative of the South - Russian scholarship is not without reason Theophanes Prokopovich not only an outstanding churchman, but also a political figure. Rationalism, enlightenment and secularization, perceived by him during his studies at the Kiev - Mohyla collegium, as well as in the Jesuit schools of Lvov, Krakow and the Roman Catholic collegium of St. Athanasius, perceived by him as the intentions of the New Age, significantly influenced how his worldview was formed.

Of considerable interest is the philosophical course of Prokopovich, read by him in the Kiev - Mohyla Academy. The manuscript of this course read over two years (1707 1709), is Prokopovich's main proper philosophical text [7]. The principal position of this course is the affirmation of matter and form as the equivalent foundations of natural bodies. In addition, in this course he undertakes a conceptual distinction between essence and existence, which is directed against the Thomist absolutism of universals and the Thomist doctrine of the coincidence of essence and existence only in the Creator, but not in His creation.

In the section of the course on universals, Prokopovich has consistently criticized the doctrine of the universals not only of the Platonists, but also of Thomas Aquinas and Duns Scott: according to Prokopovich, "universals exist, but they are not separate from individual things".

The main objection to those who assert the separate existence of general concepts is the difference between individual niches, the differences between the carriers of individual properties. Therefore, according to Prokopovich, universals do not exist either outside individual things or in individual intellect [8].

\section{PHILOSOPHICAL IDEAS OF THE REPRESENTATIVES OF THE MOSCOW SLAVIC - GREEK-LATIN ACADEMY AT THE TURN OF THE XVII - XVIII CENTURIES}

The most significant representatives of the Moscow Slavic - Greek - Latin Academy at the turn of the 17th - 18th centuries are the Likhud brothers. In the course of natural philosophy (written in 1689, began to be read in 1691), Ioannikiy Likhud analyzed the problems of matter and motion, causality, space and time, continuity and discontinuity, finity and infinity, cited information from the fields of physics and chemistry, with the activities of the human soul (psychology). In the "Introduction" to this course, Ioannicius discusses the subject of "natural philosophy", or "physics", (natural philosophy), its relation to metaphysics, and the subdivisions of this science. In the first book of "Physics" we are talking about the beginnings of things natural, such as: matter, form, "deprivation" of form, elements. In the second, the terms "nature", "art", "involuntary actions", four kinds of causes (material, formal, acting and target) are explained in detail. In the third book, the study deals with the attributes of things natural: movement, "suffering" action. In the same place is given a detailed criticism (from peripatetic positions) of the philosophical concepts of Thales, Anaxagoras, Democritus and Epicurus. Fairly believing that the essence is not formed from the accidental, Ionniki convincingly refutes the 
cosmogony hypothesis of T. Campanella, which was stated last in the work "Philosophy, proved by sensations". Campanella believed that the sky, earth, water and air spontaneously arose from the diffuse mass that was created by God. In the above-mentioned writings, the Likhud brothers resolutely defended the doctrine of freedom of the will; they considered predestination as divine prediction. In the philosophical courses of Greek teachers reigned peripatetism, coupled with the ideas of the Greek humanist Neo-Platonist.

Among the important works of Sofroniy Likhud for the history of Russian philosophy is the "Reply of Sophronius Likhud" (written in Novgorod, apparently, not later than 1711). In this late work, written much later than his removal from the rector's office in the Academy, Sofroniy Likhud attempted to answer questions posed by him, together with the Novgorod Metropolitan Job, Stefan Yavorsky and other professors of the Moscow Academy in 1711: "A philosophical question. If the soul is built up from God, then where is the impurity from? (...) The question is metaphysical. Does the water of Holy Baptism sanctify only the body or also the soul? (...) Theological question. How to explain the words of Dionysius the Areopagite: The minds of the divinity ... are connected with the beginning less and infinite illumination of the infinitely good God?" [9].

In philosophical terms, in addition to the rather traditional doctrine of the soul, the "Reply ..." is of interest because of the paradoxical delimitation of the fields of philosophy, metaphysics and theology carried out there. It is difficult to say what prompted Sofroniy to such an original act, for in his manuscript philosophical course he held to the traditional definition of the subjects of this science and theology: "Philosophy is divided into physics, which is the science of things separated from the individual (...); mathematics, which is the science of things partially separated from matter; and the divine, which is the science of things completely separated from matter" [10]. Perhaps Sofroniy was guided by traditionalist-minded zealots of Old Russian piety, who understood philosophy as a doctrine of virtuous and ascetic life. In any case, such an original understanding of metaphysics, which in Likhud's interpretation hardly differed from theology, was no longer historically correct. In the "Reply ..." Sofroniy never presented the evidentiary differences between philosophy and metaphysics, and of the last two subjects from theology, which prompted Stefan Yavorsky quite reasonably to note that all three questions of Likhud are theological. Further, Yavorsky pointed out that metaphysics is a part of philosophy, and it is impermissible and absurd to single out it as an independent discipline.

It seems that within the framework of this polemic, those "tension lines" are clearly identified, along which there is a similarity / difference between the two main forms of perception of philosophy as disciplines in Kiev and Moscow (referring to the "Likhud" period of the Moscow Academy). If South - Russian scholarship is more likely to be characterized by rationalism of the Western sense (even if perceived in scholastic forms), then Moscow scholarship tended towards more traditional medieval Russian thought models.

\section{LOGICAL IDEAS OF THE REPRESENTATIVES OF KYIV - MOHYLA AND MOSCOW SLAVIC - GREEK - LATIN ACADEMIES IN THE SECOND HALF OF THE 17TH - EARLY 18TH CENTURIES}

By the end of the 17th century, the interest in the activity and effectiveness of reason, related to its intentionality, reflexivity, and certain creative independence, was growing in the Kyiv - Mohyla Academy. When I. Giesel says that there are three creators - God, nature and art, and the latter is understood to be the creative ability of the human mind and imagination, it becomes clear that the basic ontological construction of the New Age is the isolation of the subject's sphere of consciousness, independent of the transcendental consciousness, in a separate metaphysical area, and the opposition of this area to the object (or nature), unlike the traditional dichotomy of the Creator and creature in the medieval world outlook, is not at all alien to Russian scholarship at the turn of 17th century. The effectiveness of the mind requires going beyond the bounds of the subjective and transition to a fundamentally different, constructive activity: "practical knowledge is such", writes G. Konissky, "which is not based on one cognition of the object, but goes on to his creation and control of this creation" [11].

For the philosophy of modern times as a whole, it is extremely characteristic to pay close attention to the method, the technique of correct organization of human subjectivity for the most adequate cognition of the object. At the same time, the method of the Aristotelian Organon, based on a generalization of the deductive syllogistic deduction, is clearly inadequate: the method must be sure, firstly, true, and secondly, useful knowledge. The reorientation of the logical components of philosophical courses towards the expansion of practical application (the area of logic in them is closely connected with the sphere of rhetoric) entailed significant transformations in the field of the traditional interpretation of Aristotelian logic.

Logical courses are an integral part of all the philosophical courses taught in the Kievo - Mohyla and Moscow Slavic-Greek-Latin academies. The most representative from the point of view of reflecting the basic aspirations and contradictions of the era - the transition of the medieval type to the worldview to the rationality of the new European species - are the courses of logic of Innokenty Giesel, Stefan Yavorsky, Sofroniy Likhud.

"Dialectic" and "Logic" by Innokenty Giesel, written in Latin, are works where the problems of the logical and epistemological problems themselves are not strongly enough demarcated between themselves. "Dialectics" speaks about general philosophical categories, considered from the point of view of reason [12]. "Logic" is devoted to the doctrine of the concept, judgments, and the rules of inference (syllogistic).

"Dialectic", according to Giselle, included the development of three indispensable components of any 
logical system of the time - the doctrine of the three operations of the mind. The first operation of the mind - the definition of the concept - was a sequential exposition of the basic logical constructs: the term, the sign, the name, and also the relation between the individual and the universal, between the species and the genus. At the same time, in the process of cognition, whose main task is the cognition of the general, and not of the private, the human intellect separates the meta-base of the entire pair being-nature from individual attributes and features of individual things and contemplates abstracted ideal being, which is the immanent basis of phenomena; knowing the nature, the human mind reveals the patterns of its transition from the first state, i.e. "Nature in itself", "state of indifference", to individual objects. It should be specially noted that the division and transitions of a general nature (nature in itself - the state of nature with respect to the existence of individual things - the existence of nature in the abstraction of reason) are to a considerable extent the logical operations of the human mind capable of contemplating pure entities.

The theory of genus, species and individuals of Giselle, as Ya. M. Stratii believes, is extremely close to NeoPlatonism constructions of Porphyry, to which Giesel himself repeatedly refers [13]. For Giesel, it was extremely important to determine whether a thing or concept is directly designated by words, as far as the name of a thing stands for the essence of a thing; words of modern logic, as the name refers to the meaning and denotation [14].

The doctrine of judgment (utterance) and inference (syllogism) is developed by Giesel mainly in accordance with the Aristotelian tradition. The approaches of the thinker to the problem of the truth/falsehood of statements deserve careful attention and study: if the statements about the present are subject to the law of contradiction - one of the basic laws of formal logic - then of two contradictory random sentences, according to Giesel, one will definitely be false, the other is definitely true. Syllogistics interested Giesel mostly instrumentally - as a set of inference rules that ensure its truth; "The third operation of the mind" is the science of proof. It is noteworthy that Giesel distinguishes "parcels" in proving from the "causes" of withdrawal, while considering how the premises are the cause of withdrawal, as well as the types of basic errors (circle and regress) in the proof.

And it is not by chance that Giesel ends the logical part of his course with arguments about whether science is given, what is science, what is the object of science, etc. Logic is interpreted by him as a science of a special kind, acting as a methodology of sciences.

Similarly, the main goal of logic - to be a methodology of other sciences - is determined by Stefan Yavorsky [15]. At the same time, logic is a kind of a tool for other sciences, the main task of which is to give knowledge, clear and reliable, about the world around us.

Like Giesel, Stefan Yavorsky divides the logic into two constituent parts - small and large (following the scholastic tradition, the "dialectic" and "logic", or, as we now say, the logic and theory of knowledge itself). The first part of logic is devoted, also traditionally, to the "three actions of the mind" (the doctrine of term, judgment and inference), the second to the solution of a number of general philosophical and general-geological problems, in particular, the problem of universals and the problem of "three operations of the mind" as applied to the very method of cognition [16].

Of great interest is Yavorsky's doctrine of the name. "... I like short definitions: a name is a word that inclines" [17]. An intuitive understanding of the difference between the language of formal logic and natural language is traced in the doctrine of the judgment of S. Yavorsky. He considered twenty-seven types of judgments, paying special attention to hypothetical, ie, those in which thoughts are connected not by formal, but by cause-and-effect connections. In the work entitled "Agonii peripatrtici cursus rpimus seu Logica ...", he was the first of the Russians to study the properties of the socalled material implication [18]. In addition, Yavorsky analyzed various types of conditional propositions or statements.

"The third operation of reason" - argumentation and its varieties (syllogism, entitlement, dilemma, sorit, induction) is devoted to the final, third section of "Logica vulgo dialectica" and "small logic", included in the "Philosophical competition ...". In the doctrine of syllogistics, Yavorsky tries to connect Aristotle's doctrine of the three figures of the syllogism with Theophrast (five more modes of syllogism are added). The traditional theory of proof did not completely satisfy Yavorsky, more precisely those principles of simplicity and clarity that were so characteristic of the era of the New Age [19].

The fundamental problem that Stefan Yavorsky (like other academics professors) could not avoid in his logical constructions was the problem of universals. It is generally accepted [20] that when developing the problem of universals, Yavorsky adhered to the nominalistic direction, and the detailed solution of the question of essence and existence precedes the solution of the problem of universals. "Essence" and "existence" for Yavorsky (in contrast to the Thomists) are identical categories: "all things really differ from essence and existence. Existence differs from essence only by reason», "existence is identical with what exists" Thomistic essences have no place in the nature of things, they are not necessary [21].

Approximately the same thing can be said about Plato's ideas: the universal cannot exist in the divine consciousness to single things. Thus, abstract things known to the intellect are something secondary in relation to their object; knowledge depends on individual things. "Universal nature does not exist outside its individualities as isolated..." [22]. Universals, according to Yavorsky, are constructs that are not ontological, but epistemological, and are the result of the action of the mind on the basis of the individual.

Of considerable interest is the interpretation of Aristotelian-scholastic logic, undertaken by the largest representative of the Moscow Slavic-Greek-Latin Academy, S. Likhud. In the introduction to his logical course, "Of Hieromonk Sophrony Likhud the clearest exposition of all logical action", read in 1690 - 1691, Sofroniy Likhud 
expounds his doctrine of terms as the basis for judging, with the term he means a sound having a conditional value. The course covers the components and types of terms, their division, quality and quantity. In the section on the proposal, various types of proposals were studied in particular. In the doctrine of inference, four types of syllogisms are considered (and not three, as in Yavorsky). At the end of the abovementioned "Logic", problems related to the theory of reasoning, that is, the rules of a dialectical dispute, a skillful questioning and answers, were considered. In the second section of "Logic" - "Preliminary questions about the whole logic of Aristotle" - the discussion of logic, its significance, the subject and nature of logic in general was discussed in detail. Logic was understood as a theoretical science and subdivided into didactic and applied logic. In the third section, "Explanations and questions on the "Introduction" of Porphyry", the peripatetic doctrine of a logical kind, a form, a distinctive, substantial and accidental attribute was set forth. This teaching is written in accordance with the scholastic tradition in the form of a commentary on the well-known work of the late-antique philosopher Porphyry, who, in turn, commented on the logical works of Aristotle.

The "Logic" of S. Likhud was completed with a treatise on practical and theoretical knowledge, on the correct method of cognition, and on "Explanations and questions" on Aristotle's "Categories'» and the first chapters of the first book of "Analytics".

\section{CONCLUSION}

A review of the main problems contained in the philosophical and logical constructions of I. Giesel, S. Yavorsky and S. Likhud does not at all exhaust the completeness of the themes and constructions affected by these authors in their philosophical and logical works. Without pretending to be complete, we would like to formulate some conclusions that could be the basis for further research.

- Secularization of philosophy as a whole led to the transformation of the world outlook issues - from the syncretism of the medieval world outlook to the rationality of the New Age.

- Analysis of the philosophical systems of Giselle and Yavorsky shows that following the doctrine of Duns Scott in the first and the nominalism of the second, as well as the pantheistic tendencies in the scholasticism of Sophrony Likhud, reflect the transition from medieval forms of perception of the world with the original duality of the Creator and creature to the basic ontological construction New time - the isolation of the sphere of consciousness (subject), independent of the consciousness of the transcendental, into a separate metaphysical area, and the opposition of this area to the object (or nature).

- The development of logical ideas, as necessary propaedeutics to the study of philosophy and theology, advances logic as if to the first plane of cognition - logic, along with rhetoric, becomes the methodology of the humanities.

\section{REFERENCES}

[1] V. Yu. Ivlev, Logic in Russia. The first half of the XVIII century. M.: Kogito Center, 2000, 185 p

[2] V. Yu. Ivlev, M. L. Ivleva, Peculiarities of Aristotelian scholastic logic // "Proceedings of the 2017 2nd International Conference on Contemporary Education, Social Sciences and Humanities". (ICCESSH 2017). Part of the series ASSEHR. Moscow, Russia. pp. $91-95$.

[3] I. Giesel, Opus totius philisophiae. Department of Manuscripts of the Central National Library of Ukraine, code number Mel. / M.P. 128, L.120.

[4] Ya. M.. Stratii. Problems of natural philosophy in the philosophical thought of Ukraine of the XVII century. Kiev, 1981, pp. 22 - 24.

[5] I. S. Zakhara, The struggle of ideas in philosophical thought in Ukraine at the turn of the XVII - XVIII centuries (Stefan Yavorsky). Kiev, 1982. P. 63.

[6] Unpublished works of Stefan, Met. Ryazan / Chernigov eparchial news, 1861. № 10. With. 489.

[7] Ya. M. Stratii, V. D. Litvinov, V.A. Andrushko, Description of the courses of philosophy and rhetoric of professors of the Kiev - Mohyla Academy. Kiev, 1982, pp. 208 - 217.

[8] Ibid., p. 213.

[9] Reply of Sophronia Lihud / The State Public Library. M.E. SaltykovShchedrin. Sophia meeting, No. 1427.

[10] S. Likhud, Aphantisma philosophicum // Department of Manuscripts of the RSL. F.173, No. 302. V. 127.

[11] G. Koniski, Philosophia juxta ... 1749. Department of manuscripts of the CNV of the Academy of Sciences of Ukraine. Cipher YES / P 51. C. 471.

[12] Ya. M. Stratiy, V. D. Litvinov, V.A. Andrushko, pp. 155 - 156.

[13] Ya. M. Stratii, Problems of natural philosophy in the philosophical thought of Ukraine of the XVII century, p. 23.

[14] Ibid., p. 24.

[15] S. Yavorsky. Philosophical competition, f. 592.

[16] Ibid., f. 87

[17] Ibid., f.62.

[18] N. Styazhkin, V. Silakov, A short essay on the history of general and mathematical logic in Russia. M., 1962, P. 8.

[19] S. Yavorsky, Philosophical competition, f. 87.

[20] I.S. Zakhara, The struggle of ideas in philosophical thought in Ukraine at the turn of the XVII-XVIII centuries (Stefan Yavorsky). Kiev, 1982., pp. 105-107.

[21] S. Yavorsky, Philosophical competition, f. 205 vol., 569

[22] Ibid., f. 112 vol. 